\title{
Learning Styles and Listening Strategies of EFL Learners-A Survey Study in a Medical College
}

\author{
Jie Wang ${ }^{1}$ and Fen Zhang, ${ }^{1, *}$

\begin{abstract}
${ }^{1}$ English Department, Chengdu Medical College, Chengdu, Sichuan 610038, China
\end{abstract} \\ *Corresponding author. Email: zhangfen@cmc.edu.cn
}

\begin{abstract}
In order to find out the differences in medical college students' learning styles and listening strategies and whether there is any correlation between their learning styles and listening strategies, this study is carried out. Two questionnaires are adopted in this study to survey the different learning styles and listening strategies among medical college students. Based on the experimental data, we conclude that medical college students adopt various learning styles and listening strategies in English learning and there is a strong correlation between learning styles and listening strategies. Namely, when students choose a certain learning style, they tend to adopt a corresponding listening strategy. Therefore, effective measures are put forward to help students choose proper listening strategies by choosing a suitable learning style.

Keywords: learning style, listening strategy, and learning strategy
\end{abstract}

\section{INTRODUCTION}

A lot of researches on second language acquisition focus on the individual difference among EFL learners[1]. In recent years, more and more researchers attach a lot of importance to how learning styles and learning strategies affect language learning[2]. With a shifted focus on how learners accomplish their learning tasks, the ESL/EFL classroom researchers agree that learners' making full use of their ability is critical to effective language learning. When Reid noticed that ESL students from different cultural backgrounds showed different preferences for certain learning strategies, she called for further studies in this field[2]. Since then, the researches on the correlation between learning styles and learning strategies have obtained great achievements.

Many empirical studies have revealed that learning styles have close correlation with learning strategies[3]. Although listening strategies are regarded as important components of learning strategies[4], few studies are researching the learning styles and listening strategies among medical students. At the same time, studies on the characteristics of successful language learners have proved to be a useful way to investigate how strategies affect language learning and one of the most effective ways to investigate learning strategy [5].

Medical students have taken an increasing proportion among college students in China in these years, and they are also EFL learners at different language levels. Therefore, it is very necessary to find out the differences of medical students' learning styles and listening strategies.

\section{RELEVANT CONCEPTS ON LEARNING STYLES AND LISTENING STRATEGIES}

\subsection{Definition of Learning Styles}

Since the concept "learning style" was put forward by Herbert Thelen, more than 30 kinds of theories and models concerning learning styles have emerged one after another (cited from Tan Dingliang)[6]. Different researchers held different views on the definition of learning style. Reid indicated that learning styles referred to an individual's natural, habitual, and preferred ways of absorbing, processing, and reserving new information and techniques[2]. Tan Dingliang defined the learning style as the learners' consistent, habitual, and characteristic ways of learning, which was the sum of learning strategy and learning tendency[6]. From the above definitions, a conclusion can be drawn: learning styles are the natural, habitual, preferred and relatively stable ways of individuals to absorb, process, and retain new information and skills; they contain cognitive, affective, physiological and social elements and are potential causes of learning behaviours.

\subsection{Definition of Listening Strategies}

Listening strategies are important parts of learning strategies, and they are developed based on learning strategy researches. Therefore, the definition and classification of listening strategies correspond with those of learning strategies. Ellis pointed out several characteristics to define language learning strategies, which are also applicable to the definition of listening 
strategies[7]. Hence, listening strategies can be defined as the particular methods or skills that learners use to enhance their listening comprehension capacity. They can be behavioural (for instance, taking notes while listening to help the listener to remember) or mental (for instance, relating personal knowledge or world knowledge to the listening material to improve understanding).

\section{RESEARCH METHODOLOGY}

\subsection{Subjects}

64 freshmen from Chengdu Medical College (CMC) are the subjects majoring in clinical medicine, nursing, preventive medicine and pharmacy. The vast majority of them are between 19 and 22 in age. They all have studied English for more than ten years.

\subsection{Questionnaires}

- Perceptual Learning Style Preference (PLSP) Questionnaire was an adapted version of Perceptual Learning Preferences Questionnaire (PLSP, Reid, 2002).

- Wang Yu's Listening Strategy Questionnaire (LSQ).

\subsection{Data Collection and Analysis Procedures}

All the subjects received standard listening comprehension test as the pre-test to identify the subjects' listening comprehension proficiency. 64 subjects were divided into two groups according to their test performance. The successful listeners included 32 students (scores $\geq 20$ ), and the other 32 students formed the less-successful listener group (scores $\leq 7.5$ ). Two questionnaires were distributed at different time within one week. Among the 66 copies of distributed questionnaires, 64 responses were collected and valid, in which there are 32 successful and 32 less-successful listeners. The collected data were processed by the Statistics Package for Social Sciences (SPSS25.0).

The analysis procedures were stated as follows: Descriptive statistical methods, including Minimum, Maximum, Mean and Standard Deviation, were used to analyze the frequency of students' listening strategies and the patterns of students' learning stylise. Pearson correlation analysis was used to predict the relationship between the successful and less-successful EFL learners' leaning styles and listening strategies.

\section{RESULTS AND DISCUSSION}

\subsection{General Trend of Subjects' Preferred Learning Styles and Listening Strategies}

The PLSP investigated students' six learning styles: Visual, Auditory, Kinesthetic, Tactile, Group and Individual styles in successful and less-successful listeners. From Table 1, the most preferred learning style is Tactile style $(\mathrm{M}=37.63)$, and Group style is the least preferred $(\mathrm{M}=33.00)$. The second preferred style is Auditory style $(M=37.03)$, the third is Kinesthetic style $(M=36.36)$, Individual style $(\mathrm{M}=35.47)$ and Visual style $(\mathrm{M}=33.45)$ are fourth and fifth. From the value of Standard Deviation, the smallest difference can be found in the data of Tactile style and the biggest difference can be found in the data of Individual style.

Data from Table 1 reveal that the successful and less-successful listeners of medical students prefer to learn with a variety of styles. The subjects especially prefer Tactile and Auditory learning styles. Group learning is the least preferred style for the successful and less-successful listeners of medical students.

Table 1. The Frequency of Learning Styles

\begin{tabular}{|l|c|c|c|c|c|}
\hline & $\mathbf{N}$ & Min. & Max. & Mean & $\begin{array}{c}\text { Std. } \\
\text { Deviation }\end{array}$ \\
\hline Visual & 64 & 13.00 & 50.00 & 33.4531 & 6.99417 \\
\hline Auditory & 64 & 20.00 & 48.00 & 37.0313 & 6.14112 \\
\hline Kinesthetic & 64 & 24.00 & 50.00 & 36.3594 & 5.91035 \\
\hline Tactile & 64 & 22.00 & 50.00 & 37.6250 & 5.75560 \\
\hline Group & 64 & 16.00 & 46.00 & 33.0000 & 6.65714 \\
\hline Individual & 64 & 18.00 & 50.00 & 35.4687 & 7.56132 \\
\hline $\begin{array}{l}\text { Valid N } \\
\text { (listwise) }\end{array}$ & 64 & & & & \\
\hline
\end{tabular}

Among the five strategies, the mean of meaning-focused strategies are 4.03 , ranking the first place, followed by social/affective strategies (M=3.68), mother-tonguereliance strategies $(\mathrm{M}=3.65)$, metacognitive strategies $(\mathrm{M}=3.08)$ and form-focused strategies $(\mathrm{M}=3.06)$. The Standard Deviation value indicates that the smallest difference is social/emotional strategies, while the biggest difference is mother-tongue dependent strategies.

Data from Table 2 show that all strategies are used. Students are multi-strategy-used learners. The subjects especially prefer meaning-focused strategies. Form-focused strategies are the least preferred strategy for the successful and less-successful listeners of medical students. 
Table 2. The Frequency of Listening Strategies

\begin{tabular}{|l|c|c|c|c|c|}
\hline Strategy & $\mathbf{N}$ & Min. & Max. & Mean & $\begin{array}{c}\text { Std. } \\
\text { Deviation }\end{array}$ \\
\hline $\begin{array}{l}\text { Metacognitive } \\
\text { strategies }\end{array}$ & 64 & 1.78 & 4.33 & 3.0799 & .56011 \\
\hline $\begin{array}{l}\text { Form-focused } \\
\text { strategies }\end{array}$ & 64 & 2.00 & 4.71 & 3.0580 & .60487 \\
\hline $\begin{array}{l}\text { Meaning-focuse } \\
\text { d strategies }\end{array}$ & 64 & 1.70 & 5.00 & 4.0344 & .56011 \\
\hline $\begin{array}{l}\text { Mother-tongue } \\
\text { reliance strategy }\end{array}$ & 64 & 1.00 & 5.33 & 3.6458 & .90633 \\
\hline $\begin{array}{l}\text { Social/affective } \\
\text { strategy }\end{array}$ & 64 & 2.40 & 4.80 & 3.6750 & .50079 \\
\hline $\begin{array}{l}\text { Valid N } \\
\text { (listwise) }\end{array}$ & 64 & & & & \\
\hline
\end{tabular}

\subsection{Relationship between Learning Styles and Listening Strategies}

In order to investigate the listening strategy differences in EFL learners with different learning styles, correlation analyses were conducted and the results were displayed in Table 3.

Students with Visual styles use elaboration strategy of meaning-focused strategies more often than other styles. It means that Visual learners like to choose elaboration strategy. Visual style is not correlated with metacognitive, mother-tongue reliance and social/affective strategies.

Students of Auditory styles use form-focused strategies and social/affective strategies more often than other styles and auditory styles have the strongest correlation with form-focused strategies, social/affective strategies and meaning-focused strategies. Concerning form-focused students with auditory style prefer to use grammar strategy more than new word strategy, which indicates that during conducting a listening task Auditory students usually choose the grammar strategy more frequently than new words strategy. Auditory style has no relation with mothertongue reliance strategies

Table 3. Relationship between Learning Styles and Listening Strategies

\begin{tabular}{|r|c|c|c|c|c|c|c|}
\hline \multicolumn{1}{|r|}{ Strategy } & Item & Visual & Auditory & Kinesthetic & Tactile & Group & Individual \\
\hline Metacognitive strategies & Pearson Correlation & .158 & $.281^{*}$ & .062 & $.380^{* *}$ & .243 & .140 \\
\hline Planning & Pearson Correlation & .126 & .225 & .091 & $.308^{*}$ & .229 & .131 \\
\hline Monitoring & Pearson Correlation & .170 & .242 & .015 & $.335^{* *}$ & .068 & .199 \\
\hline Self-evaluating & Pearson Correlation & .024 & $.261^{*}$ & .098 & $.289^{*}$ & $.305^{*}$ & -.009 \\
\hline Form-focused strategies & Pearson Correlation & $.296^{*}$ & $.501^{* *}$ & .093 & .074 & .167 & .179 \\
\hline New words strategy & Pearson Correlation & .197 & $.284^{*}$ & .037 & -.131 & .049 & .028 \\
\hline Grammar strategy & Pearson Correlation & $.264^{*}$ & $.497^{* *}$ & .108 & .245 & .210 & $.251^{*}$ \\
\hline Meaning-focused strategies & Pearson Correlation & .244 & $.320^{* *}$ & $.281^{*}$ & $.452^{* *}$ & $.347^{* *}$ & $.256^{*}$ \\
\hline Inferencing & Pearson Correlation & .154 & $.251^{*}$ & .240 & $.512^{* *}$ & $.344^{* * *}$ & .239 \\
\hline Elaboration & Pearson Correlation & $.312^{*}$ & $.294^{*}$ & .201 & $.291^{*}$ & .235 & $.299^{*}$ \\
\hline Prediction & Pearson Correlation & .167 & $.259^{*}$ & $.281^{*}$ & $.320^{*}$ & $.315^{*}$ & .102 \\
\hline Mocial/affective strategy & Pearson Correlation & .228 & $.406^{* *}$ & .219 & $.314^{*}$ & $.387^{* *}$ & .076 \\
\hline
\end{tabular}

**. Correlation is significant at the 0.01 level (2-tailed).

*. Correlation is significant at the 0.05 level (2-tailed)

Kinesthetic style students prefer to use meaning-focused strategies. Kinesthetic style has no relation with other four strategies.

Students of Tactile styles prefer to use metacognitive strategies, meaning-focused strategies, mother-tongue reliance strategy and Social/affective strategy. Tactile learning style has the strongest correlation with meaning-focused strategies. To the metacognitive strategies, students with Tactile style prefer to use monitoring strategy and planning strategy most. Tactile 
style has no relation with form-focused strategies. Data clearly reveal that Tactile-style students prefer to choose mother-tongue-reliance strategy. For English teachers, they ought to pay attention to the situation and help Tactile style students avoid using the mother-tongue-reliance strategy which usually hinders students' listening comprehension; for Tactile style students, it is indispensable for them to realize this correlation and try their best to adjust these listening strategies.

Group style students prefer to use self-evaluating strategy and prediction strategy more often than other styles and it is the strongest correlation with meaning-focused, social/affective strategies. Group style is not correlated with form-focused strategies.

Individual style students prefer to use elaboration strategy of meaning-focused strategies. Individual style has no relation with metacognitive, mother-tongue reliance, social/affective strategies.

Based on the data analyses and the above discussion, we can see that Auditory, Tactile and Group styles have strong impact on learning strategies. These learning strategies include metacognitive, form-focused, meaning-focused, and social/affective strategies. The result coincides with Oxford's. She believed it was likely that a strong relationship existed between the individual's use of learning strategies and individual's learning styles [9].

\section{CONCLUSION}

The study indicates the subjects adopt multiple learning styles and listening strategies instead of a single learning style and listening strategy, which is instructive for English teachers to conduct teaching, since multiple-style learners with multiple listening strategies can better improve their English listening than single-style learners with single listening strategy.

Learning styles and learning strategies have positive correlation with each other. The learning styles, as Kinsella said, when teachers introduced knowledge or skills to students through their strongest perceptual preferences and then reinforced it through secondary preferences, students learned more easily and retained far more[10]. Therefore, teachers should pay attention to students' learning styles in strategy training and make students aware of their own learning styles and learning strategies, and strengthen their favorite learning styles and strategies. The purpose is to make students become more efficient and automatic language learners.

Teachers can help learners improve or adjust their listening strategies as follows:

- When performing listening strategy training, teachers need to help students, especially Tactile and Group students, know the negative effects of mother-tongue-reliance strategy and help students get rid of it and choose more helpful strategies.
- Teachers need to strengthen Visual, Kinesthetic, Individual and Group students' consciousness of metacognitive strategy.

- Meaning-focused strategies consist of inferencing, elaborating and predicting strategies and play an important role in listening. When conducting listening strategy training or teaching in the classroom, language teachers should emphasize the importance of this strategy and tell students, especially Visual students, how to employ this strategy.

- Social/affective strategy is encouraged when listening and it is necessary to recognize the importance of this strategy for students, especially those with Visual, Kinesthetic and Individual learning styles.

In order to learn as effectively and efficiently as possible, students should identify their perceptual learning preferences, and then select learning strategies which will help them master new information by using their preferences. Students should develop flexible styles and "stretch the comfort zone" to diversify their style preferences. It is important for them to know their listening strategies and help them to choose more effective listening strategies and get rid of the ineffective ones under language teachers' help.

In conclusion, this investigation only dealt with a small part of students' learning styles and listening strategies, yet the results of this experiment are definitely convincing. Because of the limited number of experimental samples, the research results need to be further confirmed. Moreover, the results were obtained from two questionnaires, which may just represent the subjects' thoughts instead of the actual use of strategies or preference of styles. Therefore, no matter how carefully the teachers explained the subjects' understandings about questions and choices of Liken Scale could not be absolutely precise. Hence, other research methods, such as learning diaries, interviews, verbal reports and observations should be adopted to broaden the varieties of instruments to collect more abundant data and fully and precisely describe the listening strategies and learning styles. With more investigation devoted to this subject and the improvement of the research methodology, it is likely to have a better and deeper understanding of the issue of learning style and listening strategy.

\section{ACKNOWLEDGMENT}

Sichuan Foreign Language and Literature Research Center "The Application of Multimodal Metaphor in College English Vocabulary Teaching" (No: SCWYH20-10)

Sichuan Foreign Language and Literature Research Center "The Influence of Autonomous English Learning Based on Language Lab and Mobile Applications on Learners' Metacognitive Strategy Level” (No: SCWYH20-09) 


\section{REFERENCES}

[1] Dörnyei, Z., \& P.Skehan. Individual differences in second language learning. In E. Hinkel (ed.). Handbook of Research in Second Language Teaching and Learning. New Jersey: Lawrence, 2005.

[2] Reid, J. M. Learning Styles in the ESL/EFL Classroom[M]. Beijing: Foreign Language Teaching and Research Press, 2002. (Original book published 1995 by Heinle\& Heinle Publishers).

[3] Li Yan, An Empirical Study of EFL Learning Styles and Learning Strategies and Their Correlations[J], Shandong Foreign Language Teaching Journal,2009, 4, pp. 54-58. (In Chinese)

[4] Wang Yu. A study of the listening strategies employed by non-English majors in China[J], Foreign Language World, 2002,6, pp. 5-12. (In Chinese)

[5] Rao Zhehui. Individual Differences and Cultural Factors[M]. Shanghai: Shanghai Foreign Language Education Press, 2007. (In Chinese)
[6] Tan Dingliang. Learning Styles and Teaching Strategies[J], Educational Research,1995,5, pp. 72-75. (In Chinese)

[7] Ellis, R. The Study of Second Language Acquisition[M]. Oxford University Press, 1994. (Reprinted in 1999 by Shanghai Foreign Language Education Press.)

[8] Oxford, R. L. Use of language learning strategies: a synthesis of studies with implications for teacher training[M]. 1989, System 17.

[9] O’Malley, J. M., Chamot, A. U. \& L. Kupper. Listening comprehension strategies in second language acquisition[J]. Applied Linguistics 1989,10: 418-437.

[10] Kinsella, K. Understanding and empowering diverse learners in the ESL Classroom. In Reid, J. (ed.), Learning Styles in the ESL/EFL Classroom [M]. Beijing: Foreign Language Teaching and Research Press, 2002. 